\title{
Kulcsár Krisztina*
}

\section{JÓZSEF ERDÉLYI LÁTOGATÁSA 1773-BAN, ÉS UTAZÁSÁNAK HATÁSA A KÖZIGAZGATÁSRA}

\author{
Kulcsszavak: II. József, utazás, Erdélyi Nagyfejedelemség, hivataltörténet, felvilágo- \\ sult abszolutizmus
}

„Szörnyü nagy változás lett az országbeli főhivatalok között” - jegyezte fel Rettegi György emlékirataiban az 1774. évnél. ${ }^{1}$ A Doboka vármegyei nemes a személyi változások okait nem firtatta, csak a tényeket örökítette meg, és bár korábban hosszasan értekezett II. József császár 1773-ban tett erdélyi utazásáról, a kettőt nem hozta öszszefüggésbe. Jelen tanulmány azt kívánja bemutatni, melyek voltak az uralkodó látogatásának jellemzői, majd az utazás során keletkezett források segítségével azt, menynyiben volt az utazása befolyással az említett erdélyi személyi változásokra, és milyen egyéb közigazgatási változtatási javaslatai voltak a személyes felmérést követően.

II. József 1764-tôl kezdődően utazta be a Habsburg Monarchia tartományait, amelyeknek 1765-ban a társuralkodója is lett. Mindenütt arra törekedett, hogy személyesen tekintse és vizsgálja meg a körülményeket, a helyszínen szerezzen tapasztalatot a gazdasági, társadalmi, katonai állapotokról, a Bécsből küldött rendelkezések eredményeiről, és megismerje az állami alkalmazásban álló tisztviselőket. Első hivatalos utazásán 1766-ban Cseh- és Morvaországban járt, majd 1768-ban a Temesi bánságba látogatott. Ezt követően állította össze tervezetét a tartományokban teendő utazásairól, és azok sorrendjét is megszabta. ${ }^{2}$ A társuralkodó ebben feszített programot tüzött ki maga elé. Az utakat 1769 és 1772 között évente, egymás után kívánta megtenni. Ezek között utoljára következett volna Erdély és Magyarország közbenső részeinek megismerése. Miután azonban 1770-ben megtekintette a Magyar Király-

* Kulcsár Krisztina (1971), PhD, történész, főlevéltáros, Magyar Nemzeti Levéltár Országos Levéltára, Budapest. E-mail: kulcsar.krisztina@mnl.gov.hu.

1 Rettegi György: Emlékezetre méltó dolgok, 1718-1784. Közzéteszi Jakó Zsigmond. Kriterion, Buk., 1970. 331.

2 Österreichisches Staatsarchiv (a továbbiakban ÖStA), Haus-, Hof- und Staatsarchiv (a továbbiakban HHStA), Habsburgisch-Lothringische Hausarchive, Hausarchiv (a továbbiakban HausA), Hofreisen 1-2. fol. $3^{\mathrm{r}-\mathrm{v}}$. A programról lásd még Derek Beales: Joseph II. 1. In the Shadow of Maria Theresa, 1741-1780. Cambridge University Press, CambridgeLondon-New York-New Rochelle-Melbourne-Sydney, 1987. 251-255. 
ságban állomásozó lovasezredeket, és bejárta az országot, így tervezetének azt a felét már teljesítette. Az erdélyi út viszont még hátravolt. Berlász Jenő úgy vélte, II. József már 1771-ben tervezett egy látogatást, amelyet csupán Carl Claudius O’Donell tábornoknak, erdélyi fóhadparancsnoknak és a Gubernium vezetőjének a halála miatt halasztott volna el. Erre vonatkozóan azonban nem található forrásanyag. ${ }^{3} \mathrm{Az}$ viszont már forrásokkal bizonyítható, hogy egy esztendővel később, 1772-ben szeretett volna útnak indulni, és ezért a látogatását alaposan megterveztette. ${ }^{4} \mathrm{Az}$ utazás végül elmaradt, aminek pontos okát nem tudjuk. Elegendő magyarázat lehet az 1772-ben kialakult külpolitikai helyzet. Tavasszal kezdődött ugyanis a három nagyhatalom „osztozkodása" Lengyelország területei felett. Feltehető, hogy II. József ilyen helyzetben nem utazhatott el, hiszen a Habsburgok igényt tartottak a déli lengyel területekre. ${ }^{5} \mathrm{~A}$ császár 1773 februárjában ismét rendelkezett utazása megszervezéséről: ezúttal az egy évvel korábban elmaradt erdélyi látogatását akarta ötvözni a frissen megszerzett területek megtekintésével. Április 15-én indult volna útnak, Szilézián át Galícia (az új tartomány), ezután Erdély, majd a Temesi bánság következett volna. ${ }^{6}$ Mária Terézia féltette fiát az ismeretlen vidéktől, feltehetően ő beszélte le errôl a kitérőről március elején. A kompromisszumos megoldás ezért Galíciát kihagyva Magyarországon keresztül vezette volna mind oda-, mind visszaútban a társuralkodót. ${ }^{7}$ Március 7 -én

3 BerLász Jenő: Az erdélyi úrbérrendezés problémái (1770-1780). Századok 75(1941). 261.

4 Vö. Kulcsár Krisztina: II. József utazásai Magyarországon, Erdélyben, Szlavóniában és a Temesi Bánságban. Gondolat-MOL, Bp., 2004 (a továbbiakban Kulcsár: II. József utazásai). $79-164$.

5 II. József olyan fontosnak tartotta a tárgyalásokat, hogy a tervekről, a követelésekrôl és a körülményekről Lipót főhercegnek titkosírással számolt be. ÖStA, HHStA, HausA, Sammelbände 7-3. fol. 54 ${ }^{r-v}$. II. József Lipóthoz, 1772. márc. 26.; fol. 58 ${ }^{r-v}$. 1772. ápr. 19.; fol. 62 $2^{\text {r-v }}$. 1772. ápr. 20. Nem osztom Karl Gutkas véleményét, aki a külpolitikai helyzet mellett József lovasbalesetének is tulajdonítja, hogy a császár 1772-ben nem tett utazást. (Karl Gutkas: Kaiser Joseph II. Eine Biographie. Paul Zsolnay, Wien-Darmstadt, 1989. 121.) A baleset jóval a tervezett indulás után (augusztus 17 -én) történt, ez tehát nem befolyásolhatta az erdélyi látogatás időpontját. Vö. Rudolf KhevenhüLler-Metsch-Hanns Schlitter: Aus der Zeit Marias Theresias. Tagebuch des Fürsten Johann Josef KhevenhüllerMetsch, kaiserlichen Obersthofmeisters. VII. Adolf Holzhausen-Wilhelm Engelmann, WienLeipzig, 1917.138.

6 Az alapértesítések: ÖStA, Kriegsarchiv (a továbbiakban KA), Zentralstellen, Hofkriegsrat, Hauptreihe Akten (a továbbiakban ZSt HKR HR Akten) 1773-77-2; MNL OL, Erdélyi kancelláriai levéltár, Az Erdélyi Kancellária regisztratúrája, Acta generalia [B 2 - a továbbiakban MNL OL, B 2 (Acta gen.)] 1772/121. Az Udvari Haditanács Samuel Bruckenthalhoz, 1773. febr. 8.

7 Nem értek egyet Szádeczky Lajos feltételezésével, aki a Bécsben tartózkodó Bruckenthal tartományi kancellárnak tulajdonította, hogy II. József elóbb tett látogatást a szászok földjén, és csak utána utazott Galíciába, hiszen az előzetes tervekben nem is volt szó a galíciai hosszabbításról. SzÁdeczky Lajos: II. József császár útazása Erdélyben 1773-ban. Erdély - 
kelt Franz Moritz Lacy grófnak, az Udvari Haditanács elnökének a véleményezése, aki az előzetes tervekkel ellentétben inkább a fordított irányt javasolta: Magyarországról a Temesi bánságba, onnan Erdélybe, és végül vissza Magyarországra. A leiratok végül ezt az útirányt tudatták a helyi hatóságokkal. Az útvonal megváltoztatásának indoklásban az idő rövidségére hivatkoztak, amely miatt II. József nem vehetne részt a pesti táborban. ${ }^{8}$ A nyughatatlan császár ugyanis Pesten rögtön a szokásos éves katonai hadgyakorlaton szándékozott részt venni. Innen indult volna közvetlenül a stájerországi Pettauba - ismét csapatszemlére. A hosszú utazás végleges indulását május 6-ára, péntekre tüzték ki.

II. József már elindulása előtt érezhette, hogy több hónaposra tervezett utazásáról nem érkezhet vissza időben Pestre. Ezért május elején kelt rendelkezése értelmében Husztról nem Munkács irányába indult volna, hanem a Zalatna-Nagykároly-Szolnokon át vezetố úton egyenesen a tervezett katonai táborba sietett volna. ${ }^{9}$ Ezt a rendelkezését felülírta azonban egy június 12-én Erdélyben kelt újabb döntése, amely alapjában változtatott meg mindent. II. József ugyanis úgy döntött Kézdivásárhelyen, hogy amilyen hamar csak lehet, mégis készítsék elő galíciai utazását. ${ }^{10}$ Februárban ugyan még le tudta beszélni az uralkodónő őt erről az útról, Erdélyben azonban kellő távolságban volt tőle, és döntését anyja Bécsből már nem befolyásolhatta.

Az utazók rövid bánsági tartózkodás után május 21-én áthaladtak a határon, hogy mintegy két hónapot töltsenek el a Monarchia legkeletibb tartományában. A látogatás előkészítésében részt vettek a bécsi központi hivatalok: az Udvari Kamara és az Udvari Haditanács, valamint az Erdélyi Udvari Kancellária, az Erdélyi Gubernium, az erdélyi főhadparancsnokság, továbbá az egyes helyi törvényhatóságok. A fennmaradt iratok tükrözik a feltűnést kerülő császár különc kívánságait - legfő́képpen nem kívánt a meglátogatandó terület terhére lenni. Az 1773. évi utazást előkészítő uralkodói rendelet az egy évvel korábban kiadott és alaposan kidolgozott leiraton alapult. Főbb pontjai a következők:

Honismereti folyóirat. Az Erdélyi Kárpát Egyesületnek és Múzeumának Értesítője XXII(1913). 1. sz. 4.

8 ÖStA, KA, ZSt HKR HR Akten 1773-77-8. 1773. márc. 11.; MNL OL, B 2 (Acta gen.), $1773 / 205$.

9 MNL OL, Helytartótanácsi levéltár, Magyar Királyi Helytartótanács, Acta miscellanea (C 42), Fasc. 85. No. 592. fol. 196-199. 1773. máj. 8., máj. 18., máj. 27.; MNL OL, Magyar kancelláriai levéltár, A Magyar Királyi Kancellária regisztratúrája, Acta generalia (A 39), 1773/2680. 1773. máj. 27. és jún. 2. és Uo. 1773/2817. 1773. jún. 7.

10 ÖStA, KA, ZSt HKR HR Akten 1773-77-26. II. József Lacyhoz, Kézdivásárhely, 1773. júl. [sic!] 12. A datálás nyilvánvaló elírás. Vö. ÖStA, HHStA, HausA Hofreisen 7-1. fol. 249 . Nagyszeben, 1773-07-08. Itt a napló a Lembergből érkező kurírt említi, aki valószínúleg már az előkészületekről hozott híreket. 
1. A lovakat egy mellékelt lista szerint rendeljék meg. Az ezredektôl csak annyi lovat állítsanak ki, amennyi nem gyengíti őket. Az igáslovakat a polgári hatóságok, a hátaslovakat a katonaság biztosítsa.

2. Mivel az utazók főként lovagolni fognak, ezért ne a legrövidebb utat válasszák ki, hanem mutassanak meg a császárnak minden érdekességet; különösen azokat a területeket, ahol a katonai és polgári irányítás között ellentétek állnak fenn.

3. A császárt látogatásakor az ezredparancsnokok és brigadérosok kísérjék, a határőrvidéken pedig olyan katonatiszt, aki felvilágosítást tud adni mindenről (lovak, utak, ellátmány stb.).

4. A csomagokhoz és az éjszakai szállásokra biztosítsanak ôrséget, a határon és a hágóknál egy tiszt és harminc katona álljon őrségben.

5. Szállást ne kastélyban, urasági épületben vagy lakott tiszti szálláson foglaljanak le, hanem fogadókban, paplakban vagy kamarai épületben.

6. Senki ne köszöntse, ne vendégelje meg a császárt, kivéve területenként egy-egy állandóan ott lakó tisztviselő.

7. A legszükségesebbektől eltekintve ne javítsák az utakat és hidakat.

8. Bárki leadhat kérvényt, de csak aláírással ellátottat.

9. Az éjszakai szállásnál gondoskodjanak a fizetségről a lovakért és az élelmiszerért. A parasztemberek ne jelentkezzenek túl korán a váltóállomásokon, és őket a közelben lakók közül válogassák ki. ${ }^{11}$

Az útvonal megtervezésénél figyelembe vették II. József különleges úti céljait (mint a máramarosi sóbányák, a keleti határszakasz, a Moldvával folytatott határvillongásokról elhíresült terület, valamint a Beszterce vidéke és a román határőrség között vitát keltô terület ${ }^{12}$ ). A helyszínt másfél hónappal az elindulás előtt Csernátoni Ferenc főbiztossági hivatalnok vizsgálta meg egy katonatiszttel együtt. Miközben végiglovagolták az útvonalat rendes menettempóban, állomásról állomásra, ellenőrizték az utazás technikai feltételeit, a távolságokat, az útviszonyokat, a települések megközelíthetőségét. A távolságok, az útviszonyok mellett azt is feljegyezték, milyen épületek jöhetnek szóba a megjelölt éjszakai szálláshelyeken: vajon megfelelô-e a minőségük, eleget tesznek-e a császár igényének és speciális kívánságának, hogy csak kamarai épületben, fogadóban, parasztházban, paplakban, esetleg üresen álló tiszti lakban szállásolják el. A császár, az Erdélyi Udvari Kancellária és a helyszínt ismerők útiterve között eltérések fedezhetők fel. Megállapítható, hogy a császár nagyobb tá-

11 ÖStA, KA, ZSt HKR HR Akten 1773-77-16.

12 Már évekkel korábban eljutott Bécsbe a három szász falu (Nagydemeter/Dumitra, Jád/ Livezile, Pinták/Slătinița) és Beszterce vidékének román katonai kerülete közötti viszály híre, az Államtanács is foglalkozott a problémával. Vö. ÖStA, HHStA Kabinettsarchiv, Staatsrat, Protokolle 1769. Nr. 648. 
volságot kívánt egy nap alatt megtenni, mint azt a helyiek javasolták, akik több megállással, lassabb tempóval számoltak.

A 3. pont rendelkezése szerint II. József helyi kísérőit azok közül kellett kiválasztani, akik a legjobban ismerték a vidéket. Hunyad vármegye így a Gyulai-ezredből Zeyk András hadnagyot (Rettegi György szavaival: „friss, tanult, jó ember”) rendelte mellé. ${ }^{13}$ Háromszéken Kiss ezredes szolgált felvilágosítással, míg Torda vármegyében a császár a jegyzővel, Jósa Györggyel beszélgetett út közben. ${ }^{14}$ II. József utazásának egyik legismertebb krónikása, Michael Konrad von Heidendorf medgyesi nótárius 1773. június 2-án, majd július 11-én ismételten kísérte a társuralkodót, majd a látogatást személyes tapasztalata alapján örökítette meg terjedelmes emlékiratában. ${ }^{15}$

1773-ban minden egyes éjszakai szálláshelyen tizenhárom házat kellett biztosítani az utazók és katonai kísérőik számára. ${ }^{16}$ II. Józsefnek általában három házat jelöltek ki szálláshelyül és a közös étkezésre. Ezek egyikének rendelkeznie kellett olyan méretủ helyiséggel, ahol tizenkét személy elfért. Ezekben a házakban kaptak helyet a császár lakájai, titkára és személyes kísérői. A katonatiszteknek és tisztiszolgáknak két-két különálló házat foglaltak le, az erdélyi kísérők szintén külön épületben szálltak meg. Erdélyben a kietlen vidékeken a határ menti vesztegzárállomásokat jelölték ki erre a célra, de éjszakáztak a magukkal vitt sátrakban is: amikor például a Borgóiszoroshoz lovagoltak, sátraikat a használaton kívüli vesztegzárház mellett verték fel. ${ }^{17}$

A vármegyéknek 1773-ban váltóállomásonként 74 igás- és 18 hátaslovat kellett készenlétben tartaniuk, a kijelölt 88 váltóállomást tekintve ez 6512 lovat jelentett, amelyeket a törvényhatóságoknak kellett biztosítaniuk - ez olykor csak nehézségek árán sikerült. ${ }^{18} \mathrm{Az}$ erdős hegyvidéken sokszor hátaslovakon lovagoltak, ezekről a katonaságnak kellett gondoskodnia. Az utazók Erdélyben általában 8-13 órányit lovagoltak, de néha csak hat órát töltöttek nyeregben. Amikor sürübben lakott vidéken

13 Rettegi: i. m. 299; ÖStA, HHStA, HausA Hofreisen 7-1. fol. 54r. Livádia, 1773-05-22.

14 Uo. fol. 137v. Zágon, 1773-06-10; Uo. fol. 164r. Szászrégen, 1773-06-18.

15 Uo. fol. 99v. Talmács, 1773-06-02. Vö. Michael Conrad von Heidendorf: Eine Selbstbiographie. Közzétette Rudolf Theil. Archiv des Vereins für Siebenbürgische Landeskunde. N.F. XVI(1880). 426-498; JANcsó Benedek: A román nemzetiségi törekvések története. I-II. Lampel Róbert (Wodianer F. és fiai), Bp., 1899. II. Lásd az 1-21. lapok között a II. József utazásairól szóló részt, amelyet a jegyző visszaemlékezései alapján állított össze.

16 MNL OL, Erdélyi országos kormányhatósági levéltárak, Gubernium Transylvanicum levéltára, Gubernium Transylvanicum, Ügyiratok [F 46 - a továbbiakban MNL OL, F 46 (Ügyiratok)], 1773/2354. Körrendelet, 1773. márc. 30.; Uo. 1773/1809. Nemes János fóbiztos az Erdélyi Guberniumhoz, 1773. márc. 2. Vö. Kulcsár: II. József utazásai 117-118.

17 Vö. ÖStA, HHStA, HausA Hofreisen 7-10. fol. 736-741; Uo. Hofreisen 7-1. fol. 167v. Borgói vesztegzárállomás, 1773-06-20.

18 ÖStA, KA, ZSt HKR HR Akten 1773-77-8, MNL OL, F 46 (Ügyiratok), 1773/2764. Körrendelet, 1773. márc. 30. 
közlekedtek, nagyobb települések, például Gyulafehérvár és Szászsebes, majd Kolozsvár és Torda között, általában kocsival utaztak. A május 21-i határátlépést követő több mint egy hónap alatt 273 órát és 30 percet utaztak lóháton. Ez napi átlagban (az öt pihenőnapot leszámítva) 8 órát jelent, ami igencsak megterhelő lehetett az utazók számára. ${ }^{19}$ II. József idősebb kísérőit állítólag annyira kifárasztotta a lovaglás, hogy azt kérték a társuralkodótól, ne kelljen napi 16 órát egyhuzamban a nyeregben tölteniük. József ezért engedélyezte, hogy előreutazzanak Máramarosszigetre, ahol július 9-től 13-ig „éjjel-nappal ágyban fekve” várták a császár megérkezését. ${ }^{20}$

II. József és kísérete lehetőség szerint fogadókban, míg a katonai határőrvidéken az erődben étkezett, élelmüket néha megosztották a helyi tisztekkel is. ${ }^{21}$ Minden egyes éjszakai szállásra a következőket kellett előkészíteni, amelyből a magukkal vitt szakácsok vacsorát főztek: 70 font marhahús, 1 egész borjú, 1 egész bárány, 24 csirke, 3 lúd, 2 tyúk, 2 pulyka, 6 font vaj, 4 font zsír, 40 darab tojás, 2 pint liszt, 2 font cukor, 8 citrom, 4 font szalonna, 4 font ökörzsír, zeller, petrezselyem, hagyma, (kel)káposzta, 2 font savanyú káposzta, fehér kenyér, rendes bor stb. ${ }^{22}$ Látható, hogy a trónörökös ezen a listán semmi különlegeset, semmi luxuscikket nem rendelt. Nem szerepel például a vadhús, igen kevés a konyhai füszer vagy egyéb főzési hozzávaló. Borból sem különlegeset, nemeset (például tokajit vagy somlóit) rendeltek, hanem a helyben beszerezhetőt. Az elszámolásokból azonban tudjuk: Erdélyben és Galíciában is költöttek cukrászsüteményre, rendszeresen rendeltek tejet, sőt tejszínt is. 1773-ban 12 pintnyi, vagyis csaknem 17 liter pálinkával vágtak neki az utazásnak - ez fertőtlenítésre is szolgálhatott. A különlegességeket, fúszereket feltehetően magukkal szállították Bécsből, mint például teát, kávét - mivel az elszámolások külön tételként nevezik meg a császárvárosban vásárolt teás- és kávésdobozt, valamint azt, hogy az út alatt a kávéskanna fogóját kétszer is meg kellett javíttatniuk. ${ }^{23} \mathrm{~A}$ helyi szervezőknek az élelmiszereken kívül „sok minden más”-t is elő kellett készíteniük: konyhai eszközöket, edényeket, tányérokat, késeket, villákat, kanalakat és poharakat, abroszt, konyharuhá-

19 ÖStA, HHStA, HausA Hofreisen 7-10. fol. 732 ${ }^{\text {r-733v }}$. Marcheroute Sr. Mayestät des Kaysers durch Siebenbürgen. (1773. máj. 21-től júl. 10-ig.) A folytatásra lásd a tervezetet uo. fol. 736-741. Abgeänderter Antrag zur Fortsetzung der Reyse Sr. Mayestat des Kaysers von Hermanstadt aus.

20 Szilágyi István: Második József corregens és trónörökös Máramarosban, 1773. Máramaros 23(1887). 29. sz. (1887. júl. 20.)

21 ÖStA, HHStA, HausA Hofreisen 7-1. fol. 50v-51. Livádia, 1773-05-22.

22 ÖStA, KA, ZSt HKR HR Akten 1773-77-26. 1 font = 0,56006 kg; 1 (bécsi) pint = 1,4147 liter.

23 ÖStA, HHStA, Hofarchive, Obersthofmeisteramt, Hofwirtschaftsamt B. Sonderreihe. rote Nr. 34. Reisen 2. Verschiedene Reise Berechnungen Sr. Maj. Joseph II. 1773. Post Speesen Consignation. Bécs, 1773. szept. 24. (régi jelzet) 
kat, valamint 40 zsúp szalmát a fekhelyekhez. ${ }^{24} \mathrm{Az}$ evőeszközöket és tányérokat ónból, fából vagy agyagból kellett beszerezni: még ezen a téren sem volt megengedett a fényüzés.

A császár látogatásának hamar híre ment a nagyfejedelemségben. Mária Terézia így tudósította Milánóban élő Ferdinánd fiát: „az emberek bolondulnak érte, még soha nem láttak császárt, és ily szeretetreméltót és népszerüt, de ami a leginkább ámulatba ejti őket: ily mértéktartót és egyszerűt, a bálokon nem vesz részt, ez hihetetlennek tünik számukra”. ${ }^{25} \mathrm{Az}$ alattvalók számára meglepő lehetett, hogy a társuralkodó kerülte a fényűzést és a feltúnést. II. József ugyan megtiltotta a hivatalos fogadásokat, ünnepléseket, de azt nem tudta (és nem is akarta) megakadályozni, hogy az alattvalókkal, a néppel kapcsolatba kerüljön. ${ }^{26} \mathrm{~A}$ császár ugyan a hivatalos ceremónia, kötöttségek ellen volt, de anyja ismerte őt, és helyesen látta: József egyáltalán nem volt érzéketlen a tiszteletadás iránt, és tetszett neki, ha hódolattal járultak elé. ${ }^{27} \mathrm{Az}$ uralkodói látogatáson fellelkesült tömegek patetikus hangvételű költeményekkel, kőbe vésett versekkel köszöntötték az ifjú társuralkodót. ${ }^{28}$

A parancs ellenére erdélyi vendéglátói számos fogadást és bált rendeztek a császár tiszteletére. II. József útinaplói azonban nem csak ezekről a programokról tanúskodnak, hanem munkája szeretetéről is, és arról, milyen ellenszenvet érzett a társadalmi szereplések, kötelezettségek iránt: „Utána, bár színházba akartak vinni, én fél nyolckor hazamentem, és a naplón dolgoztam”. ${ }^{29} 1773$. május 30-án Nagyszebenben megjelent Bethlen Miklós grófnál, ahol többek között nyolc játékasztalt is felállítottak, de már fél 10-kor faképnél hagyta az összesereglett erdélyieket. Amikor közel egy hónap múlva ismét a városban járt, a gróf újabb estélyt adott tiszteletére. A császár naplója megjegyzéseiből következtetve - a kínok kínját élhette át a fülledt levegőjü palotában. Beszélgetni nem tudott senkivel, mert „akkor húszan állottak körül, és tolakodóan hallgattak. Fél óra szenvedés után hazamenekültem”. ${ }^{30}$ Július 1-jén egy estélyre volt hivatalos, amelyet Haller János egykori gubernátor özvegye rendezett.

24 ÖStA, KA, ZSt HKR HR Akten 1772-77-1.

25 Mária Terézia Ferdinánd főherceghez, 1773. jún. 10. Közölte: Briefe der Kaiserin Maria Theresia an ihre Kinder und Freunde. I-IV. Hrsg. Alfred Ritter von Arneth. Wilhelm Braumüller, Wien, 1881. I. 211.

26 Lásd Kazinczy elbeszélését a császár Sárospatakon nyilvános elköltött ebédjéről: KAzıNczy Ferenc: Pályám emlékezete. Abafi Lajos, Bp., 1879. Első könyv, első szakasz, 17-18.

27 Mária Terézia Mercy grófhoz, 1774. febr.3. Közli: W. Fred [Alfred Wechsler]: Briefe der Kaiserin Maria Theresia. Németre fordította Hedwig Kubın. I-II. Georg Müller, München-Leipzig, 1914. II. 136.

28 Kaiserlich Königlich allergnädigst privilegirte Anzeigen aus sämtlichen Kaiserl. Königl. Erbländern III(1773). XXX. sz. 233-234; MNL OL, B 2 (Acta gen.) 1772/486; 1773/774. Dési József költeménye.

29 ÖStA, HHStA, HausA Hofreisen 7-1. fol. 8v. Temesvár, 1773-05-11.

30 Uo. fol. 90v. Nagyszeben, 1773-05-30; fol. 202 ${ }^{\text {r }}$ Nagyszeben, 1773-06-29. 
Gyulai Ferenc szerint a császár nyájasan társalgott a jelenlevőkkel - József saját bevallása szerint azonban igen sok ember és irtózatos forróság volt ott. Korábbi ironikus megjegyzéseit ismerve, feltehetően mégsem érezhette magát olyan jól, mint ahogy az a tábornoknak tünt. ${ }^{31} \mathrm{~A}$ császár utolsó nagyszebeni estéjén még benézett a Teleki gróféknál összegyưlt társasághoz, majd rövid időre az operába - ennyi elég is volt neki, hogy megállapítsa: „a színház nagyon keskeny és hosszú, ami nem jó a hangzásnak". ${ }^{32}$

Mivel a császár keresztül-kasul beutazta a nagyfejedelemséget, személyesen is találkozott a magyar vármegyék főispánjaival, a székely és a szász székek királybíráival. Nagyszebenben továbbá II. József maga is részt vett a különféle kormányszervek ülésein, ahol az ügymenetről tájékozódott, a megtárgyalt és elővezetett tárgyakról latin nyelvű kivonatot kapott kézhez, sőt saját feljegyzéseket is készített. ${ }^{33} \mathrm{~A}$ hivatalokat, az ügymenetet, a tisztviselők munkavégzését így nem csak másodkézből vagy mások elmondásából, esetleg az utazás előkészületei során számára előre összeállított jellemzésekből ismerte meg. ${ }^{34} \mathrm{~A}$ tanácsüléseken, de Erdélyben egyébként is számos alkalommal szembesült azzal, hogy az egyes nemzetek (és egyidejüleg a felekezetek) képviselői a hivatali rendszeren belül is harcot folytattak egymással, és igyekeztek saját embereiket elhelyezni a közigazgatásban. A helyzeten az erdélyiek szerint rontott az ún. Proportio Geometrica, a hivatali ügyvitelt megnehezítő vallási paritás elve. ${ }^{35}$ $\mathrm{Az}$ 1691-től bevezetett rendszer alapján ugyanis azonos számban kellett a Guberniumban és az erdélyi királyi tábla ülnökei között az ország bevett vallásainak: katolikusnak, reformátusnak, evangélikusnak és unitárius vallásúnak helyet kapnia. Ezen a rendelkezésen annyiban módosított az ún. Alvincziana Resolutio, hogy ,az üresedésben lévő tisztségek megfelelő evangélikus és unitárius személyek hiányában úgy töltendők be, hogy katolikusok és reformátusok között egyenlőség legyen”. ${ }^{36}$ II. József, aki bármiféle kivételezés ellensége volt, ami által alkalmatlan, tehetségtelen személyek jutottak érdemtelenül jelentős posztra, azon a véleményen volt, „hogy ezt az előírt egyenlősködést teljesen meg kellene szüntetni, és a jövőben a hivatalokat mindig a legméltóbbaknak kell odaítélni, tekintet nélkül az országban bevett vallá-

31 Gróf Gyulai Ferenc tábornok emlékiratai, 1714-1787. Közli Torma Károly. Hazánk VVI(1886). 686; ÖStA, HHStA, HausA Hofreisen 7-1. fol. 206r. Nagyszeben, 1773-07-01.

32 Uo. fol. 258v. Nagyszeben, 1773-07-10.

33 Uo. fol. 83. Nagyszeben, 1773-05-29. (itt tiszteletüket tették a hivatalnokok); fol. 257"rv Nagyszeben, 1773-07-10.

34 Uo. fol. 71. Angestellte Generals...; Uo. Hofreisen 8-4. fol. 1256-1263. Samuel Bruckenthal előterjesztése (Bécs, 1773. ápr. 28.) és erdélyi tisztviselők listái.

35 Uo. Hofreisen 7-1. fol. 185r. Dés, 1773-06-24. Beszélgetés Teleki Károllyal.

36 TRócsánYi Zsolt: Habsburg-politika és Habsburg-kormányzat Erdélyben, 1690-1740. Akadémiai, Bp., 1988 (A Magyar Országos Levéltár Kiadványai III. Hatóság- és Hivataltörténet 8). 203, 227, 229. 
sokra” ${ }^{37}$ A császár a rendszer legnagyobb hátrányát a kötött számok biztonságában látta. Mivel a katolikus vallásúak kevesen voltak, ôk biztosítottnak láthatták, hogy a paritás elve miatt álláshoz jutnak, ezért nem kell küzdeniük, és munkájukat is elhanyagolhatták. A protestánsok ellenben, akik jóval nagyobb létszámban éltek Erdélyben, emiatt esélytelennek érezhették magukat az álláshoz jutásnál. Az egyedüli megoldást esetleg a konvertálásban látták volna - erre több hivatalnok, például Bethlen Gábor egykori udvari kancellár esete jó példa. ${ }^{38} \mathrm{~A}$ bécsi Államtanács tagjai a proportio eltörlése esetében attól féltek, hogy így háttérbe szorulnának a katolikus hivatalnokok. Kinevezésüknél - elvileg - ugyanis az udvarnak az erdélyiek által jelölt személyek közül kellett választania. Ha azonban nem kell kötelezően egyenlő arányban jelölni és alkalmazni katolikusokat és reformátusokat, úgy félő volt, hogy a katolikusok a protestánsok túlsúlya miatt még csak a jelöltek közé sem kerülnének be. Ezért a kevés számú katolikusnak semmi esélye nem lenne, sőt elveszthetnék reményüket, hogy valaha is hivatalhoz jutnak. ${ }^{39}$

A vallási hovatartozás azonban II. József számára már ekkor is másodlagos volt, a legfontosabb mércéje az alkalmasság és a tehetség volt. A császár nem csak információkat gyüjtött a magas posztot betöltő személyekről, a hivatalos audienciák is hozzájárultak a helyzet megismeréséhez, így legtöbbször saját személyes tapasztalatát helyezte előtérbe. A társuralkodó az általa vallott elvek alapján az egyes hivatalnokoknál az értelmet, a tudást és a hasznosságot vette figyelembe. Ennek jó mérőeszköze volt például egy kérdéssorozat, amelyre a császár értelmes, használható válaszokat és javaslatokat várt. Külön változatot készítettek a guberniumi tanácsosok, illetőleg a főispánok, és külön egy másikat a kincstartóság tagjai számára. ${ }^{40}$ Például: Milyen a kapcsolata a kincstartóságnak és a Guberniumnak? Milyen az ügyvitel? Hogyan lehetne ezen javítani? Milyen állapotban van az igazságszolgáltatás, és hogyan lehetne jobbá tenni? A kérdések felölelték mindazon témákat, amelyeket a császár Bécsbe visszatérve az Államtanács elé tárt jelentésében, így például a közigazgatási átszervezéstervezeteket, az ügymenet javítását, a sószállitásokat és a jobbágyok terheinek könnyítését, a Szamos hajózhatóvá tételét, bányászati ügyeket, só- és fakitermeléseket, az erdőségek állapotát. II. József rákérdezett arra is, hogy kártalanították-e már a katonaságnak átengedett területek tulajdonosait. Rettegi György véleménye

37 ÖStA, HHStA, HausA Hofreisen 7-8. fol. 623".

38 Vö. RetTegr: i. m. 149.

39 ÖStA, HHStA, HausA Hofreisen 7-8. fol. 625 $5^{\mathrm{r}-\mathrm{v}}$.

40 A guberniumi tanácsosokhoz és a főispánokhoz intézett: Uo. Hofreisen 8-4. fol. $1264^{\mathrm{r}}-1267^{\mathrm{r}}$. Puncta super quibus quilibet Tabularum Praeses, Supremus Comes, ac officialis Majestati Suae Caesareae plenam informationem, opinionemque Suam conscientiose scripto exponet; a Thesaurariatus tagjaihoz: Uo. fol.1251 ${ }^{\mathrm{r}}-1252^{\mathrm{v}}$. Puncta, worüber jeglicher der Herrn Thesaurariats Räthe allerböchst Sr. des Kaisers Maj. die vollständigen Auskünften nach seinen gewissenhaften Befund und die pflichtmässige Woblmeynung schriftlich zu eröfnen haben wird. 
lesújtó volt a fôtisztviselőkről: szerinte a 15 pontos kérdőívet mindössze ketten, Teleki Károly, valamint Kendeffy Elek tudja majd önerőből megválaszolni, a többiek pedig mással csináltatják meg. ${ }^{41}$ József kérdéseire rendkívüli mennyiségú: közel 200 fóliónyi, német és latin nyelvủ válasz érkezett - ezek kiértékelése feltehetően már egykorúan nagy munkát jelentett; a későbbi rendeletekkel való összevetésük pedig a jelenkor történészeinek ad feladatot.

Ahogy Rettegi Györgynek a cikk elején idézett mondatából tudjuk, az 1774. évben jelentős változások történtek Erdélyben: a július 1-jén kiadott uralkodói rendelet értelmében számos vezetô tisztviselő és hivatalnok, továbbá főispán és királybíró kicserélődött vagy más posztra került.. ${ }^{42} \mathrm{~A}$ rendelet ugyan nem hivatkozik rá, de egyértelmúen feltételezhető II. József hatása. A császár az utazás után ugyanis titkos listát készített a nagyfejedelemség hivatalnokairól, rövid, de találó megjegyzésekkel anyja számára. ${ }^{43} \mathrm{Ha}$ összevetjük jellemzéseit az 1774. évi változásokkal, figyelemre méltó eredményre jutunk. A leirat éppen azokat nyugalmazta (jubilálta), akiket a császár titkos listájában használhatatlannak, betegnek, öregnek, haladásellenesnek jellemzett. A tehetséges, becsületes, ígéretes erdélyiek (akár szász, akár magyar nemzetiségúek, akár katolikus, akár protestáns hitúek voltak) újabb megbízatást kaptak.

A leváltottak között szerepelt például Teleki László guberniumi tanácsos, aki megtestesítette mindazt, ami József felfogása szerint a megújulás ellentéte volt: „Idős ember, aki teljesen a nemzeti előítéletek rabja. Van némi gyakorlata az ügyintézésben, a reformátusoknak mondhatni ő a pápa. Mindennemú újítás esküdt ellensége, különösen a szászoké [...]”. ${ }^{44}$ Tehetségesnek, de érdekembernek jellemezte Nemes János országos főbiztost, aki ennek ellenére még néhány évig bizalmat kapott, és 1777-ig posztján maradhatott: „A legjobb korban levő férfiú, akinek Erdély-szerte egyhangúan elismerik eszét, éleslátását, értelmét, tehetségét, valamint képességeit, de ugyanilyen egyértelmúen minden oldal azt állapítja meg róla, hogy majdnem ilyen rosszindulatú, nem becsületes gondolkodásmódú, hamis és különösen érdekember. Amenynyire kiismerhettem, semmilyen vonatkozásban nem leltem nála őszinte indulatra. Minden megnyilatkozása többértelmü, csavaros volt [...]”. ${ }^{45}$

41 Rettegi: $i . m .304$.

42 MNL OL, F 46 (Ügyiratok), 1774/6092. A kortárs mindezen változtatásokat Samuel Bruckenthal befolyásának tulajdonítja, véleményem szerint tévesen. RETTEGi: i. m. 331, $335,387$.

43 A lista közölve, hiányosan: Khevenhüller-Metsch-Schlitter: i. m. VII. 447-451; kiegészítve: Kulcsár Krisztina: II. József jellemzései az erdélyi hivatalnokokról 1773-ból. „Az Erdélyben hivatalnokoskodó guberniumi és kincstartósági tanácsosok, továbbá a fóispánok és a királybirók titkos listája, amennyire kiismerhettem őket”. Fons IX(2002). 1-3. sz.359-385. Az eredeti lelőhelye: ÖStA, HHStA, HausA Hofreisen 8-2. fol. $1037^{\mathrm{r}}-1041^{\mathrm{v}}$.

44 Uo. fol. 1037v.

45 Uo. fol. $1038^{\text {r. }}$. 
Többen teljesen alkalmatlannak tűntek II. József számára. A gubernium elnöke ekkor Bethlen Miklós kincstartósági tanácsos volt: „Nem tudok róla mást mondani, mint amennyire ki tudtam venni a beszélgetésekből és tetteiből, hogy egy jó ember, aki azonban nem irányításra termett. Sem beszélni, sem írni nem tud, és tétlensége ismert mindenki előtt, aminthogy az is, hogy Strohmayer titkára végez mindent, és mindent aláírat vele, amit csak akar". ${ }^{46}$ Haller Gábor guberniumi tanácsos pedig „egyike azoknak, aki ámbátor tábornok és a guberniumi tanácsosok egyike, azonban azt se tudtuk volna róla, hogy nehezíti a földkerekséget, ha nem Grassalkovich gróf lányát (egy csinos és helyre asszonyt) vette volna feleségül”. ${ }^{47}$

A leváltottak helyére olyanok kerültek be a főkormányszékbe, akiket József személyesen ismert meg a látogatás alatt. Ilyen volt Kendeffy Elek, aki Hunyad vármegye főispánságától vált meg, és lett guberniumi tanácsos. „Úgy vélem, ez a férfi becsületes, félénk, de az igazságszolgáltatásban igen képzett" - írta a császár naplójában, majd a listájában így jellemezte: „Oly ember, aki sem küllemét, sem beszédét tekintve egyáltalán nem mutatkozik előnyös oldaláról, de ha kissé hosszabban beszél vele az ember az ügyekról, látható, hogy olyan, aki alapos és tisztességesen gondolkodik. Mintha csak túl jóságos lenne". ${ }^{48}$ A katolikus vallású Teleki Károlyt is dicsérte a listájában: „Az ő tekintélye a legnagyobb Erdélyben, mindenki méltányolja tisztességes gondolkodásmódja, tehetsége és belátása miatt. Az egyetlen [hibája], amelyet találtam, hogy már túlságosan eltávolodott a világtól és aszketikus, s bizonyára aggodalmaskodó; egyébként oly ember, aki biztosan alkalmas mindenre, amire használni akarnánk. Katolikus.” A gróf Belső-Szolnok vármegye fő́ispánságát cserélte le a guberniumi tanácsosi posztra, majd a Gubernium mellett múködő ún. tartományi kancellária vezetője volt. Karrierje később is töretlen maradt: 1782-1783 folyamán ő irányította a kincstartóságot. Meggyengült egészsége miatt azonban saját maga kérte nyugdíjazását.

A tehetséges guberniumi titkárok (Michael Bruckenthal, Michael Ahlefeld) szintén előbbre léptek a ranglétrán. Georg Andreas Rosenfeld tanácsjegyzői címet és munkakört kapott. A császár mindhármójukat következőképpen jellemezte: „fiatalok, akik szorgalmasak, tanultak és reményt keltők”. Bekerült a tanácsosok közé egy idős szász guberniumi titkár is: Stephan Hannenheim ismereteinek és tapasztalatainak köszönhette kinevezését. ${ }^{49}$

Jelentős változások történtek a törvényhatóságok élén is - Rettegi külön itt sem indokolja ennek okát. Több vármegye és szék elöljárója időközben elhalálozott, de

46 Uo. fol. $1037^{\text {r. }}$

47 Uo. fol. $1037^{\mathrm{v}}$.

48 Uo. Hofreisen 7-1. fol.60r. Déva, 1773-05-23. Beszélgetés Kendeffy Elekkel; Uo. Hofreisen 8-2. fol. 1040 .

49 Uo. fol. $1038^{v}$. 
számos olyan akadt, akiket II. József alkalmatlannak minősített. Miske Imre Aranyosszék élén egy „elaggott vénember, oly furcsa tulajdonságokkal, hogy inkább gyerekesnek és félbolondnak tartom. Hatalmas kereszttel a mellkasán jár fel-alá és mindenütt keresztet vet" ${ }^{50}$ Mivel ő 1774-ben elhunyt, helyére Huszár Sándor került. A hatalmas méretű Fehér vármegye éléről 800 forint nyugdíjjal ,jubilálták” Haller Pált: „Olyan férfi, aki egyáltalán nem megfelelő egy ily hatalmas, az egész országot [ti. Erdélyt] áthálózó vármegye [irányítására], mindenki holdkórosnak tartja, röviden alkalmatlan a hivatalra, amelyet ellát [...]" ${ }^{51} \mathrm{~A}$ nehezen irányítható vármegyét kettéosztották, egyik részébe Kemény Simon került, aki korábban Kraszna főispánja volt. Felső-Fehér vármegye élére Haller Antalt nevezték ki, vele II. József Küküllő vármegyei átutazásakor találkozott. Az adminisztrátori minőségben dolgozó férfit szorgalmasnak, „nem ügyetlennek”, de eltorzultnak ismerte meg, és ellenére volt nemzeti elfogultsága. ${ }^{52}$ A gróf „a Theresianumban tanult, de nem sok nyoma maradt, különben szorgalmas, és nem tűnik ügyetlennek, de már eléggé elvadult". Kinevezését feltehetően annak köszönhette, hogy használható javaslatokat tett a császár kérdőpontjaira. ${ }^{53}$ A „félbolond” és beteg, összetört Domokos Antal helyére, Marosszék élére Halmágyi István kapott kinevezést, Udvarhelyszéken pedig az elhunyt 90 éves fókirálybíró fiát, az addigi adminisztrátor Daniel Istvánt erősítették meg.

A személyes ismeretség a későbbi évek hasznára vált: többek ennek köszönhették előrejutásukat. A református Bánffy Farkas egyike lett József erdélyi „reformembereinek”, pedig a társuralkodó hamar átlátott rajta: „Oly ember, akiről mindenki belátást, ügyességet és tudást feltételez. Néhányan ugyan azt állítják, hogy titokban intrikál, de ez nem bizonyított. Református, és elég csak vele beszélni vagy hallani, ahogy referál, látható, hogy olyan ember, aki ismeri az ügymenetet, azok irányítását, és van önuralma. Bizonyos, hogy ez az ember, ha akarja, Ôfelségtek szolgálatában nagyon sok jót tud tenni, és igen jól használható. Azonban oly kevéssé őszinte, hogy minden szava ravasz, csavaros, és mondhatni egy igazi jezsuita, teljesen összefonódott Nemes [Jánossal], és következésképp a szász táborral, mint ahogy Bruckenthallal is titokban levelezést folytat”. A későbbi évek során Bánffy mégis számos tisztségben bizonyíthatta a császár által megtapasztalt rátermettségét: 1777 és 1782 között országos főbiztosként, 1787-től pedig a kincstartóság elnökeként múködött.

Az első találkozáskor még igen fiatal (mindössze 27 éves) fiatalember, Bánffy György hasonlóképpen több különböző poszton bizonyíthatta, hogy megérdemli a bizalmat. 1787-től haláláig, 1822-ig a legmagasabb erdélyi hivatalt, a gubernátor

50 Uo. fol. 1040v. Vallási buzgalmára lásd Rettegr: i. m. 318-319.

51 Rettegi először tévesen írja 1765-nél, majd helyesen 1774-nél. RetTegr: i. m. 193, 332. ÖStA, HHStA, HausA Hofreisen 8-2. fol. 1039.

52 Uo.

53 Uo. és Hofreisen 7-8. fol. 616 . 
tisztjét töltötte be. 1773-ban a császár így vélekedett róla: „Egy fiatal, nagyon fiatal ember, azonban tehetséges és dolgos, ezt elismerik, csak kissé öntelt, és rossz főnök irányítása alatt könnyen teljesen elromolhat [...]”.

Az 1774-ben bekövetkezett erdélyi tisztújítás váltást jelent a nagyfejedelemség addigi kormányzásában. Talán a társuralkodó hatását érezhetjük abban, hogy az erdélyi kulcspozíciókat nem Bécsből „odaerőszakolt” külföldiek töltötték be, hanem az alkalmasnak mutatkozó helyiek közül választották ki. Megállapítható, hogy ők azonosak a II. József által dicsért személyekkel, azokkal, akikre felfigyelt, és akik tehetségéről kétséget kizáróan meggyőződött. Egyeduralkodása alatt, de különösen az új erdélyi vármegyék megszervezésekor azokra a megbízható személyekre támaszkodott, akiket még 1773-ban megismert: Michael Ahlefeldet, Andreas Rosenfeldet, Teleki Ádámot, Kemény Simont, Halmágyi Istvánt, Michael Bruckenthalt. ${ }^{54}$

II. József Erdélyből visszatérve egy merész közigazgatási tervet, (akkor úgy tűnt) talán a legilluzórikusabb elképzelését tárta Mária Terézia és az Államtanács elé. II. József szerint a nagyfejedelemségben „mindenütt rosszindulat, csalás, intrika uralkodik, és mindegyik fél — tekintet nélkül a közjóra — csak arra törekszik, hogy a másik [fél] megrövidítésére és letaszítására alapítsa [a hivatalnoki posztokra] felvételét és felemelkedését". ${ }^{55}$ Ezért azt javasolta, hogy vonják össze Erdélyt (a határőrvidék kivételével), a partiumi vármegyéket, Máramaros vármegyét és a Bánságot. Központjául Nagyváradot jelölte volna ki. Az így kialakított terület Horvátországhoz hasonlatos módon kapcsolódott volna a Magyar Királysághoz. Indoklása szerint a sokféle, sok nemzetiségből álló, eltérő jogállású alattvalók között így kiegyenlítődnének a különbségek, és ebben a közigazgatási rendszerben megszúnne a nyugtalanság, a féltékenykedés és az ellenségeskedés. ${ }^{56} \mathrm{~A}$ bécsi tanácsadók határozottan elutasították a császár tervét, úgy vélték, a szóba került országokban nem azonosak a törvények, a rendelkezések és a privilégiumok. II. Józsefnek ezt az elképzelését nem értesületlenségével vagy naivságával magyarázhatjuk, hanem az egységes államról vallott elvével. Ebben pedig nem volt helye egy olyan, a többi tartomány igazgatásától teljesen eltérő berendezkedésű területnek, mint a Bánság vagy a különböző jogállású és privilégiumokkal rendelkező lakosságú Erdély. Számára elfogadható lett volna a rendek megjelenése a kialakított „vegyes” területű Erdély - Máramaros - Bánságban is, bár feltehetően nem a magyar állapotok szerinti korlátozott rendi államot akarta volna alapul venni.

Az 1774-ben bekövetkezett személyi változások, majd II. Józsefnek az egyeduralkodóként kiadott rendeletei sokszor alapjaiban változtatták meg az addig megszokott erdélyi állapotokat. Ehhez, ahogy láthattuk, a hátteret az utazások alatt szerzett

54 MNL OL B 2 (Acta gen.), 1784/1311; 1786/535.

55 ÖStA, HHStA, HausA Hofreisen 7-8. fol. 608 . Kivonat az erdélyi úti jelentésből.

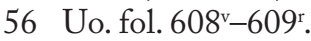


személyes tapasztalatai biztosították - de ne feledkezzünk meg a 16148 darab beadványról, kérvényről és panasziratról, amelyeket az alattvalók az előkészítő rendelet 8. pontja értelmében nyújtottak át neki. Ezek is további felvilágosítást adtak a társuralkodónak az erdélyi állapotokról - de ez egy másik tanulmány témája. ${ }^{57}$

\title{
THE TRAVEL OF JOSEPH II IN TRANSYLVANIA IN 1773 AND ITS IMPACT ON THE TRANSYLVANIAN ADMINISTRATION
}

\author{
Keywords: Joseph II, travelling, Grand Principality of Transylvania, the history of the \\ public institutions, enlightened absolutism
}

Joseph II embarked on his journey in Transylvania (and Galicia) between the $6^{\text {th }}$ of May and the $13^{\text {th }}$ of September 1773 in order to familiarize himself with the two provinces of the Habsburg Monarchy. In order to lessen the financial burden of his visits on his subjects, the emperor neglected the protocols of the ceremonial court travellings, and opted for a simpler, thus more cost-efficient way of organizing it. 'Incognito' in his perception did not mean travelling in secret under a false identity, rather a particular way of organizing and undertaking his journey. His primary aim was to avoid the prescribed ceremonial elements of a court travel, its suffocating etiquette, social obligations and festivities. He travelled by a simple and not an elegantly decorated coach or by horse, and was accompanied by a small number of hand-picked confidants. Several authorities were implicated in the organizing process. The Transylvanian Court Chancellery forwarded the decrees of the Emperor and the planned route to the Transylvanian Gubernium, which instructed the Transylvanian counties, seats and districts of their duties. They had to provide provisions for relays and for accommodating quarters, and to perform only the necessary maintenance works of the roads and bridges. The local military authorities were informed, too, by the Imperial War Council. In Transylvania the Transylvanian General Commando of Sibiu (Nagyszeben) was in charge of the preparations, and the military troops had the duty to supply the travelers with saddles, horses, and military escort.

Being a co-sovereign charged with the military problems of the Empire, Joseph II was interested in particular in inspecting the fortifications and the military troops of the Grand Principality. He also had the chance to gather personal impressions on the appointed bureaucrats and on the functioning of the whole administrative network of Transylvania. During his audiences and other informal conversations, he took thorough, often ironical notes on the professional knowledge, abilities and efficiency of the office-holders, and their personal opinion on various subjects. These personal notes show the young Joseph' proficiency in evaluating the personalities of his subordinates. As a consequence of his visit, in the next year important changes were made in the administration of Transylvania: the activity of certain offices was reorganized, and several leading officials were dismissed, reassigned or new ones were commissioned. Our sources clearly indicate that the newly assigned officials were those who made a good impression on Joseph II during his journey, and they were to become the new leading officials of the 1770s and 1780s (or even after these decades) in Transylvania.

57 Kulcsár Krisztina: II. Józsefhez intézett beadványok 1773. évi erdélyi látogatása során. Erdélyi Múzeum 68(2007). 3-4. sz. 246-253. 


\section{VIZITA LUI IOSIF AL II-LEA ÎN TRANSILVANIA DIN 1773 SI IMPACTUL ACESTEIA ASUPRA ADMINISTRAȚIEI PRINCIPATUULUI}

\section{Cuvinte-cheie: losif al II-lea, călătorie, Marele Principat al Transilvaniei, istoria instituțiilor publice, absolutism luminat}

Împăratul Iosif al II-lea a călătorit în Transilvania (și Galiția) între 6 mai și 13 septembrie $1773 \mathrm{cu}$ scopul de a se familiariza cu cele două provincii ale Imperiului Habsburgic. Ca să ușureze povara financiară a vizitei sale, împăratul nu a respectat protocolul obișnuit al vizitelor ceremoniale somptuoase ale curții, ci a optat pentru o organizare mai simplă și astfel mai ieftină. "Incognito" în accepțiunea sa însemna nu că a călătorit în secret sub o identitate falsă, ci modul particular al organizării și derulării întregii căătorii. Scopul său primordial a fost evitarea elementelor ceremoniale somptuoase, a etichetei sufocante, a obligatiilor sociale și a festivităților prescrise de protocoalele călătoriilor curții. În locul unor atelaje bogat împodobite a călătorit cu trăsuri simple fiind însoțit de o escortă restrânsă la număr, dar membri căreia au fost atent aleși. Mai multe instituții s-au implicat în organizarea călătoriei. Astfel, Cancelaria Aulică Transilvană a transmis Guberniului din Transilvania dispozițiile imperiale precum și datele rutelor planificate, Guberniul instruindu-i apoi pe reprezentanții comitatelor, scaunelor și a districtelor în privința sarcinilor lor. Aceștia din urmă aveau obligația de a asigura schimbul cailor și cazarea împăratului, de asemenea să asigure întreținerea drumurilor și a podurilor folosite. Consiliul Imperial de Război a contactat de asemenea comandamentele militare supreme din teritoriile vizate și conducerile teritoriilor de graniță. General Commando-ul transilvănean cu sediul în Sibiu a fost însărcinat cu organizarea pregătirilor în Transilvania. Armata a avut de asemenea un rol important în organizarea călătoriei, aceasta având obligația de a asigura escorta militară a călătorilor cu toate cele necesare (cai, etc.).

Fiind însărcinat cu problemele militare ale Imperiului, Iosif al II-lea s-a interesat în primul rând de inspectarea fortificațiilor și a regimentelor Marelui Principat. A avut de asemenea ocazia îi întâlnească personal pe conducătorii diferitelor instituții ale Principatului și să verifice modul în care funcționa întregul sistem administrativ al Transilvaniei. Atât în cursul audiențelor oficiale, cât și cu ocazia convorbirilor informale și-a făcut însemnări amănunțite, adesea ironice despre cunoștințele profesionale, abilitățile și eficiența funcționarilor întâlniți, cât și despre opinia lor privind diferite probleme ale vieții politice și nu numai. Aceste însemnări dovedesc faptul că, în ciuda tinereții sale, Iosif al II-lea a fost un bun cunoscător al firii umane și avea abilitatea de a evalua într-un timp scurt cele mai importante trăsături ale personalității supușilor săi. Ca o consecință imediată a vizitei împăratului, în 1774 s-au făcut importante schimbări în administrația Transilvaniei: activitatea unor instituții a fost reorganizată, mai mulți funcționari au fost schimbați sau relocați, iar alți noi au fost numiți în diferite poziții. Sursele noastre indică clar că oficialii nou desemnați au fost cei care cu ocazia întâlnirilor personale au făcut o impresie bună asupra lui Iosif al II-lea, aceștia fiind și cei care vor alcătui viitoarea generație a funcționarilor Transilvaniei din anii 1770 respectiv 1780 (sau chiar și după aceste decenii). 